\title{
Public Policy, Start-up Entrepreneurship, and the Market for Venture Capital
}

\author{
Keuschnigg, Christian; Nielsen, Søren Bo
}

Document Version

Final published version

Publication date:

2006

License

CC BY-NC-ND

Citation for published version (APA):

Keuschnigg, C., \& Nielsen, S. B. (2006). Public Policy, Start-up Entrepreneurship, and the Market for Venture Capital. Department of Economics. Copenhagen Business School. Working Paper / Department of Economics. Copenhagen Business School No. 15-06

Link to publication in CBS Research Portal

\footnotetext{
General rights

Copyright and moral rights for the publications made accessible in the public portal are retained by the authors and/or other copyright owners and it is a condition of accessing publications that users recognise and abide by the legal requirements associated with these rights.

Take down policy

If you believe that this document breaches copyright please contact us (research.lib@cbs.dk) providing details, and we will remove access to the work immediately and investigate your claim.
}

Download date: 26. Apr. 2023 
Copenhagen

Business School

HAN DELSH ØJSKOLEN

\section{Department of Economics}

Copenhagen Business School

Working paper 15-06

Public Policy, Start-up Entrepreneurship, and the Market for Venture Capital

Søren Bo Nielsen

Christian Keuschnigg 


\title{
Public Policy, Start-up Entrepreneurship, and the Market for Venture Capital*
}

\author{
Christian Keuschnigg \\ University of St. Gallen (IFF-HSG), CEPR and CESifo \\ Soren Bo Nielsen \\ Copenhagen Business School, EPRU, CEPR and CESifo
}

2006

\begin{abstract}
In recent years, venture capital has become an important source for financing young entrepreneurial firms. Given the apparently more innovative nature and extra value added of venture capital backed firms compared to other firms, policy makers have taken an increasing interest in an active venture capital industry. We explore how selected policy instruments determine the incentives of individuals to start up new firms and of venture capitalists to finance and advise them, and how policy thereby influences the size and nature of the industry and how it affects aggregate welfare. We examine the impact of wage and corporate income taxes as well as capital gains taxes and start-up capital subsidies on the volume and quality of venture capital backed entrepreneurship.
\end{abstract}

JEL-Classification: D82, G24, H24, H25

Keywords: Entrepreneurship, venture capital, double moral hazard, taxes, subsidies.

Address: Keuschnigg: Varnbuelstrasse 19, CH - 9000 St. Gallen, Switzerland. Phone: +41-71-224 -2520/ -3085, Fax: -2670, Email: christian.keuschnigg@unisg.ch Nielsen: Solbjerg Plads 3, DK-2000 Frederiksberg, Denmark. Phone: +45-3815 -2596, Fax: -2576, mail: sbn.eco@cbs.dk

${ }^{*}$ This paper is the background paper for our eponymous chapter in Simon Parker (ed.): The Life Cycle of Entrepreneurial Ventures, International Handbook Series on Entrepreneurship, vol. 3, Springer 2006. 


\section{Contents}

1 Introduction $\quad 2$

$\begin{array}{lll}2 & \text { A Model of Start-ups and Venture Capital } & 7\end{array}$

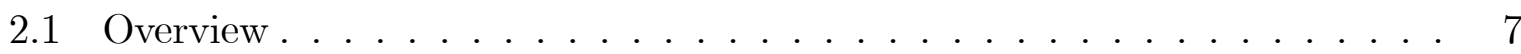

2.2 Consumption and Savings . . . . . . . . . . . . . . . . . . . 9

2.3 Mature Firm Value and Investment . . . . . . . . . . . . . . . . 10

2.4 VC Financed Start-ups . . . . . . . . . . . . . . . . . . . . . 12

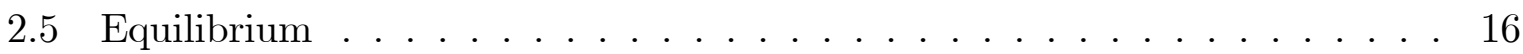

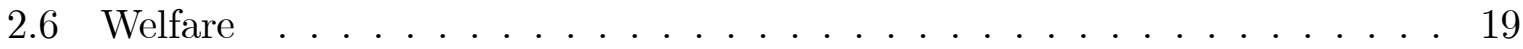

3 Policy and the Venture Capital Sector $\quad 20$

3.1 Corporate Taxation . . . . . . . . . . . . . . . . . . 21

3.2 Capital Gains Taxes and New Firms . . . . . . . . . . . . . . . . . 25

3.3 A Subsidy to the Cost of Capital . . . . . . . . . . . . . . 27

3.4 Wage Taxation . . . . . . . . . . . . . . . . . 30

4 Conclusions $\quad 30$

5 Mathematical Appendix $\quad 35$

A Effort, Advice and Profit Sharing . . . . . . . . . . . 35

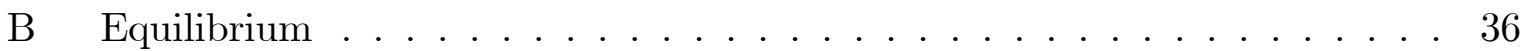

B.1 Supply of New Firms . . . . . . . . . . . . . . . . 36

B.2 Demand for New Firms . . . . . . . . . . . . . . . 37

B.3 Equilibrium Venture Returns . . . . . . . . . . . . . 37 


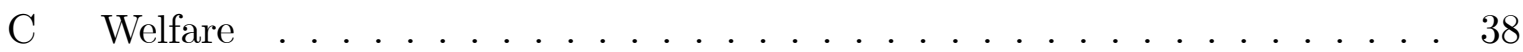

D Output and Entrepreneurship . . . . . . . . . . . . . . . 39 


\section{Introduction}

Among new entrepreneurial firms in high-technology industries, venture capital (VC) has increasingly become an important player, not only as a source of finance but also as a source of professional support. The firm's transition from birth of the idea to a marketable and profitable product not only involves technological experiments and development of prototypes. Acquiring new facilities, developing marketing strategies, attracting key clients and reliable suppliers, hiring new personnel, team building, and raising further financing to expand the business requires formidable managerial expertise and entrepreneurial experience. While proficient at the technological side, start-up entrepreneurs not only lack the necessary capital but are also in dire need of professional assistance. Seasoned venture capitalists (VCs) are well suited to fill these gaps. They have good access to capital, are endowed with own managerial experience and detailed knowledge of the industry, and can count on a well developed network of suppliers, customers and key personnel. Indeed, the defining characteristic of $\mathrm{VC}$ is the combination of finance and commercial assistance. In contrast to passive bank financing, VCs arrange for entrepreneurs to receive support in various ways: they create links to suppliers and possible customers; they get hold of key personnel; they provide strategic and marketing advice, etc.

Venture capital started out in the U.S. some four decades ago and has vigorously grown in the last twenty years. By now, almost half of new firms which are sold off at IPOs (Initial Public Offerings) have been backed by VC (see Gompers and Lerner, 2001). In Europe, the introduction of VC started significantly later, and only in the most recent years have VC firms become prominent financiers of young technology-firms. Recent statistics published by EVCA (the European Private Equity and Venture Capital Association) report a total investment by members of the Association of 29.1 billion Euros in 2003. ${ }^{1}$ Like in previous years, strict seed and start-up investment constituted a minor part of the total amount (some 2.2 billion Euros or 7.4 pct.), the rest being expansionstage investment and financing of buyouts etc. The EVCA statistics further reveal marked

\footnotetext{
${ }^{1}$ See the EVCA Press Release on EVCA Final Figures for 2003, June 3, 2004.
} 
differences across countries. The UK, Sweden and France have the relatively largest Private Equity/VC industries in Europe, several times larger than those of countries like Denmark and Austria.

Young entrepreneurial firms are considered an important source of innovation and employment. Policy makers and the business community have thus taken a strong interest in healthy conditions for financing new firms, and in the development of an active $\mathrm{VC}$ industry in particular. Several important questions arise when developing a policy perspective. Is there enough risk capital available? Do administrative procedures and requirements hinder entrepreneurship in the first place? Are government grants and subsidies to new firms appropriate? Do taxes block the creation and development of start-ups? The VC industry itself surely considers public policy to be relevant and keeps an eye on whether the general policy environment is suitable to promote the development of private equity and venture capital and to encourage entrepreneurship. For instance, EVCA in 2003 and again in 2004 published a benchmarking report on the tax and legal environment in its member countries (cfr. EVCA, 2004). ${ }^{2}$ The assessment evaluates 13 indicators relating to both the supply-side (i.e. investors in private equity and $\mathrm{VC}$ funds and fund managers investing directly in companies) and the demand-side of private equity and VC (i.e creation of entrepreneurial firms). Among the tax indicators covered are (i) company tax rates, with special attention to those applicable to small and medium-sized companies; (ii) capital gains tax rates for individuals; (iii) income tax rates for private individuals; (iv) tax incentives for individual investors investing in private equity; (v) the entrepreneurial environment; and (vi) fiscal incentives to enhance research and development.

The benchmarking report defined a favorable tax environment by the following criteria (points 3.6 to 3.9 and 3.11 on p. 7 in the report): (i) Company tax rates, especially for small and medium sized enterprises should help to support entrepreneurship. (ii) A favorable tax treatment of the sale of unquoted investments in growth companies is an appropriate incentive to entrepreneurial investment. (iii) Income tax rates for private

\footnotetext{
${ }^{2}$ See also the related Press Release from EVCA of May 24, 2004.
} 
individuals should support, attract and retain human capital, in particular entrepreneurs, researchers and highly qualified company managers. (iv) Tax incentives should be adopted for individual investors investing in private equity funds. (v) Fiscal R \& D incentives should be adopted.

The benchmarking report can only be taken to reflect a firm belief in taxes mattering for entrepreneurship. Many empirical contributions to public finance do indeed testify to the general importance of taxes for entrepreneurship. For example, Rosen (2004) in summarizing his research with a series of co-authors produces ample evidence that once started, the decisions in new firms regarding employment, capital investment and production are markedly influenced by taxes. Gentry and Hubbard's (2000) empirical analysis demonstrates that the progressivity of the tax schedule is important for entrepreneurship, while Cullen and Gordon (2002) find that lower personal income taxes in fact reduce entrepreneurship because of the lower tax value of offsetting losses.

Besides this general literature on entrepreneurship there is little theoretical or empirical work on the effects of public policies on VC financed entrepreneurship. Exceptions are a couple of contributions by Poterba (1989a,b) and Gompers and Lerner (1998) which investigate how capital gains taxation affects the demand for VC via entrepreneurs' career choice and the supply of VC in terms of funds raised. Further, our own previous theoretical work has aimed to shed light on the relation between taxes and VC-backed entrepreneurship (see Keuschnigg, 2003, 2004a-b, and Keuschnigg and Nielsen, 2003a-b, $2004 a-b)$.

The present chapter investigates selected taxes and subsidies such as those emphasized by the EVCA benchmarking report mentioned above, and explores how they impact on VC financed entrepreneurship. In particular, we examine a subsidy to start-up investment representing the various investment grants, interest subsidies, subsidies to capital expenditure in research and development which are prevalent in many countries. We explore the taxation of capital gains in new firms when sold off to new investors, the taxation of wages in occupations alternative to the pursuit of an entrepreneurial career, and corporate 
income taxation. Although the corporation tax is paid mainly by more mature firms with positive profits, it is nevertheless rather crucial to start-ups as well since it is capitalized in firm value and thereby affects the price at which successful new firms can be sold off after the start-up phase.

Our primary focus is on the consequences of taxes and subsidies on the rate of business creation and the quality of VC financing in industry equilibrium. We set up a two-period equilibrium model that is rich enough to reveal the effects of taxes and subsidies on as well the survival probability of start-ups, IPO prices and capital investment of mature firms, as welfare. The core of the model is the relationship between a finance-constrained entrepreneur and a VC firm that must pay for the new firm's physical investment expenses. The firm's success rests on the entrepreneur's effort and due diligence, as is well established in the empirical literature (such as that reviewed in Rosen, 2004). It also reflects the VC's engagement and contribution to the firm as argued above (see Kaplan and Stromberg, 2001, for a concise statement of the stylized facts) and empirically documented by Gompers and Lerner (1999) and Hellmann and Puri (2000, 2002), among many others. The empirical evidence on VC value added in Europe is more controversial (see Bottazzi and Da Rin, 2002, for a skeptical view. Audretsch and Lehmann, 2003, arrive at a more positive picture).

It seems that the productive contribution of VCs to business growth is not a guaranteed matter and may rest on the existence of appropriate incentives on the part of VCs. Finance theory has addressed these incentives in terms of a double-sided moral hazard problem, where both the entrepreneur and VC must exert effort in the company (see Holmstrom, 1982; Aghion and Tirole, 1994; Casamatta, 2003; Inderst and Mueller, 2004; Repullo and Suarez, 2004; Schmidt, 2003; and our own previous work mentioned above). Since neither party's effort is observable and contractible, the VC contract must be carefully crafted to provide appropriate incentives to both the entrepreneur and VC. In focussing on the real effects of $\mathrm{VC}$ in industry equilibrium, we postulate a particularly simple model of the entrepreneur's and VC's interaction that gives rise to a simple Pareto-optimal 
contract that can be implemented by a straight equity contract. Although real world VC contracts contain many additional elements such as staging, control rights and convertible securities, these non-monetary incentives may be considered more like complements rather than substitutes to the incentives provided in a financial contract (see Hart, 2001).

Within our simple model, the contract specifies that the $\mathrm{VC}$ acquires an equity stake for a price that covers at least the physical start-up costs plus possibly an upfront payment to the entrepreneur. The agreed profit sharing is chosen to optimally allocate incentives to the entrepreneur and VC in order to maximize the joint surplus to be divided among them. Although profit sharing is optimally chosen, it nevertheless implies that each party is able to appropriate only a share of the marginal gains from putting forth extra effort while she will have to bear the entire private cost of doing so. For this reason, entrepreneurial effort and VC advice tend to be too low compared to a socially efficient allocation.

No such distortion is present in our model with respect to the rate of business creation. The literature has indeed been very skeptical towards policies that simply aim to promote the rate of business creation. In fact, it often argues for a tax rather than a subsidy to entry (cfr. De Meza, 2002; see also the discussion in Cressy, 2002, and Parker, 2003). From a normative point of view, our model does not support policies to accelerate business creation either but rather argues for a better quality of start-ups. It supports policies that do not aim at more but rather more successful firms VC backed firms. There is a quality-quantity trade-off.

Most real world policies towards young firms subsidize the cost of capital from startup investment. Policy analysis within our model shows that these subsidies are indeed effective in stimulating entrepreneurship but are questionable from a broader welfare perspective. Precisely because they are effective in generating entry, they tend to depress market prices and firm values which ultimately erodes the rewards to private effort. Since effort is too low in private equilibrium, these subsidies tend to reduce welfare. Capital gains taxes have an ambiguous effect on entrepreneurship while they may be quite harmful in welfare terms. Wage taxes lead individuals into entrepreneurial careers, but likewise 
may be unwarranted from a welfare angle. Instead, taxes on entrepreneurs would be more sensible, leading to fewer but more successful and more valuable firms. Finally, corporate income taxes are likely to affect entrepreneurship negatively since they reduce the value of mature companies and thereby impair the reward to effort in start-up firms. Very importantly, this will be the case even if the corporate income tax is of the cash-flow tax type which is neutral to investment in mature firms. Quite generally, any policy reducing the value of mature companies will feed back negatively on incentives within start-up firms. To state our arguments more precisely, we set up an equilibrium model in section 2 and provide a formal policy analysis in section 3. Section 4 concludes.

\section{A Model of Start-ups and Venture Capital}

\subsection{Overview}

Figure 1 illustrates our two-period model of young and mature firms. The sequence of events unfolds from left to right. At the beginning of the first period, the government defines a policy environment, consisting of the policy instruments listed at the bottom of the figure. The entrepreneurial and traditional sectors produce a perfectly substitutable output with a price normalized to unity. Production in the traditional sector is Ricardian, converting one unit of labor into $W$ units of output, and thus paying a fixed wage $W$. The traditional sector absorbs all labor resources not demanded by the entrepreneurial sector. There is a population of mass one of agents. Weighing the prospects of an entrepreneurial career against employment in the traditional sector at a safe wage $W$, a mass $E$ of agents opts for entrepreneurship to pursue their business ideas. The remaining population $(L=1-E)$ chooses employment. The occupational choice decision of individuals thus

shifts production to one or the other sector. In the second period, output is supplied by entrepreneurial firms only, traditional firms being inactive.

An entrepreneur must first undertake a seed investment to turn her idea into a project and develop a business plan. For this purpose, individual $i$ needs to incur a non-pecuniary 
investment of $h^{i}$. Individuals are assumed to differ in their basic inventiveness. Some create their project at low cost while others have to put in more effort. Lacking own resources to start the firm, an entrepreneur proposes a deal to a VC firm to finance and advise the venture. When accepting the contract, the $\mathrm{VC}$ acquires a share $1-s$ in the firm, leaving a share $s$ to the entrepreneur, against a total price $B+(1-z) I$ that covers at least the private start-up cost $I$ net of a possible government subsidy $z$ plus an extra upfront payment $B$ to the entrepreneur. The parameters $s$ and $B$ of the contract are optimally chosen to reflect the relative importance of the expected contribution to the firm's success.

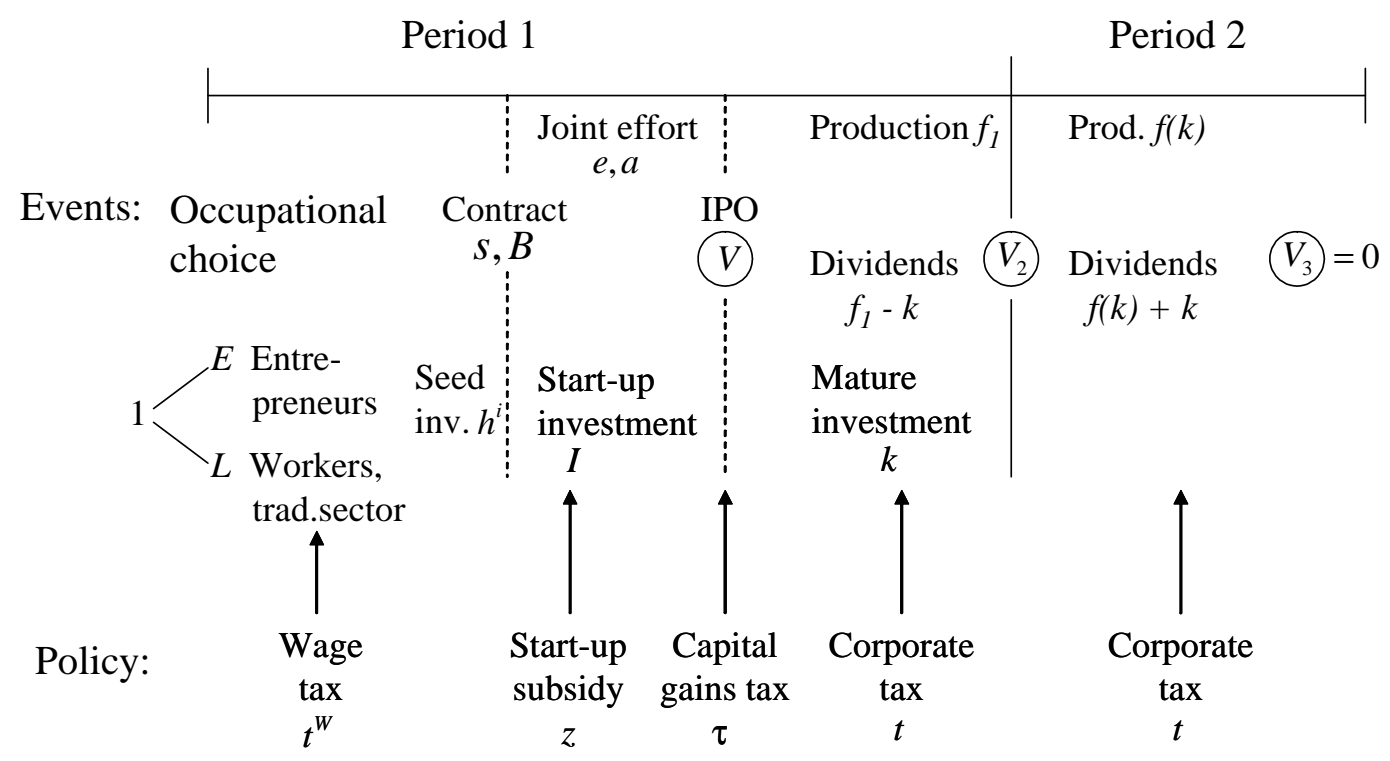

Figure 1: Events and Notation

Having specified the terms of the contract, the firm is started up with the fixed investment $I$. The venture is risky. Both the entrepreneur and the $\mathrm{VC}$ must put in effort to enhance the firm's chances. The likelihood of success is specified as $p=p(e, a)$ and depends on entrepreneurial effort $e$ and VC advice $a$. If a venture succeeds, production starts, and the firm can be sold to new investors, possibly at an IPO, for a price $V$. If it fails (with probability $1-p$ ), the firm will be shut down without any production and 
revenues whatsoever. When firms successfully mature to production stage, they produce $f_{1}$ for the remainder of the first period. A part $k$ of this production is retained and invested internally to accumulate capital, while the residual is distributed as dividends to owners. In the second period, production $f(k)$ is continued at a level depending on mature firm investment $k$. Revenues are paid out to owners. The capital stock $k$ is assumed to depreciate in full over the second period. Depending on the level of wages or entrepreneurial income received, individuals save in the first period to choose optimal life-cycle consumption.

The policy instruments to be investigated are: $t^{W}$ a tax on wage income; $t$ a corporate income tax on mature firms; $\tau$ a capital gains tax on new firms, levied symmetrically on entrepreneurs and VCs; and $z$ a subsidy to start-up investment. A fraction $\theta, 0 \leq \theta \leq 1$, of mature firm investment $k$ can be expensed in the first period from the corporate income tax, even though capital only depreciates in the second period. The remaining part $1-\theta$ is deducted from the tax base in the second period. Government budget imbalances are offset with a lump-sum taxes or transfers, where $T_{1}$ and $T_{2}$ denote the lump-sum payments in the two periods. The next subsections solve the model by backward induction, in the reverse order of Figure 1, and starts with intertemporal consumption choice, given income as determined by earlier events.

\subsection{Consumption and Savings}

A simple specification of preferences for present and future consumption, $X^{i}$ and $D^{i}$, is given by $U^{i}=X^{i}+u\left(D^{i}\right)-l^{i}$, where $l^{i}$ is effort of agent $i$, depending on her occupation. Effort of workers is normalized to zero. When consumption is decided upon, effort on the part of entrepreneurs is already sunk and income depending on success or failure is given. Denoting by $y^{i}$ discounted individual income, intertemporal consumption follows from

$$
U^{* i}=\max \left\{X^{i}+u\left(D^{i}\right)-l^{i} \quad \text { s.t. } \quad X^{i}+D^{i} / R \leq y^{i}\right\},
$$

where $r$ denotes the rate of interest and $R=1+r$ the discount factor. 
Ownership of VC firms is broadly dispersed over the population. Everyone thus receives VC profits equal to $\Pi$ per capita. At the end of period 1, a worker has wealth (present value of income) $y^{i}=\left(1-t^{W}\right) W+T+\Pi$, where $T$ stands for the present value of government transfers, $T=T_{1}+T_{2} / R$, and $t^{W}$ is a proportional wage tax. A successful entrepreneur has a wealth of $y^{i}=(1-\tau)(s V+B)+T+\Pi$, while a less fortunate one is left with $y^{i}=(1-\tau) B+T+\Pi$ only. When selling the share $1-s$ to the $\mathrm{VC}$ at the beginning of period at a price $(1-z) I+B$, she realizes a capital gain on the initial investment $(1-z) I$. At IPO, she realizes a further capital gain $s V$, and pays a capital gains tax at rate $\tau$. An unsuccessful entrepreneur receives no further capital gains.

Given separable preferences, consumption and savings follow from $u^{\prime}\left(D^{i}\right)=1 / R$. All agents thus demand the same amount of second period consumption, with $D^{\prime}(R)>0$. Savings are thus identical as well. Income heterogeneity simply leads to different levels of present consumption. Indirect utility results upon substituting out $X^{i}$ in (1),

$$
U^{* i}=y^{i}-l^{i}+C(R), \quad C(R) \equiv u(D)-D / R .
$$

Welfare of an individual agent equals life-time wealth adjusted for effort cost plus consumer surplus $C(R)$ which, by construction, is uniform across agents.

\subsection{Mature Firm Value and Investment}

A mature firm is assumed to pay net of tax dividends $\chi_{1}=(1-t) f_{1}-(1-\theta t) k$ and $\chi_{2}=(1-t) f(k)+(1-\theta) t k$, where $f_{1}$ is a fixed amount of first period output and $f(k)$ is a standard production function. A part $\theta$ of mature firm investment is immediately expensed against the corporation tax; the remaining part reduces the tax bill next period. This definition of dividends assumes internal investment finance. At IPO, the value $V$ of a mature firm reflects the present value of the net dividend flows $\chi_{1}$ and $\chi_{2}$. Paying out a dividend $\chi_{1}$ at the end of period one leaves a value $V_{2}$ at the beginning of period 2 . In period 2, another dividend of $\chi_{2}$ is paid out, leaving a value of $V_{3}=0$ at the end of the period, when the world ends. Therefore, from the date of IPO to the end of period 2, 
mature firms run down their value to zero on account of dividend payments. No-arbitrage conditions nail down firm values $V$ and $V_{2}$ in capital market equilibrium,

$$
0=\chi_{1}+\left(V_{2}-V\right), \quad r V_{2}=\chi_{2}-V_{2} .
$$

The first equation states that the sum of dividends and (negative) capital gains must be zero in the latter part of the first period since interest is zero within period. During the second period, dividends and net-of-tax capital losses must add up to a rate of return that matches the interest $r$ from an alternative investment of $V_{2}$. Substituting the dividend definitions in these no-arbitrage conditions yields $V_{2}=\chi_{2} / R$ and $V=\chi_{1}+V_{2}=\chi_{1}+\chi_{2} / R$ which is rearranged as

$$
V=(1-t) f_{1}+V_{1}, \quad V_{1}=\frac{(1-t)[f(k)-u k]}{R}, \quad u \equiv \frac{(1-\theta t) R-(1-\theta) t}{1-t} .
$$

The part $V_{1}$ is that part of firm value which is optimized with respect to mature firm investment. First note how interest and tax parameters affect the user cost of capital,

$$
\frac{d u}{d R}=\frac{1-\theta t}{1-t}, \quad \frac{d u}{d t}=\frac{(1-\theta) r}{(1-t)^{2}}, \quad \frac{d u}{d \theta}=-\frac{t}{1-t} r .
$$

Maximizing with respect to mature firm investment $k$ yields

$$
f^{\prime}(k)=u \quad \Rightarrow \quad \frac{d k}{d R}<0, \quad \frac{d k}{d t} \leq 0, \quad \frac{d k}{d \theta}>0 .
$$

Since the corporate income tax raises the cost of capital, it reduces mature firm investment. If $\theta=1$, however, so that capital investment can be immediately expensed, the corporate income tax becomes a cash flow tax, neutral to investment (presuming a positive corporate income tax). An increase in the rate of immediate investment expensing promotes investment if the tax rate is positive. Finally, a rise in the interest rate tends to lower investment in mature firms.

Using the envelope theorem, the effects of taxes on mature firm values are

$$
\frac{d V}{d R}=-\frac{V_{1}+(1-\theta t) k}{R}, \quad \frac{d V}{d \theta}=t \frac{r k}{R}, \quad \frac{d V}{d t}=-\frac{V}{1-t} \Gamma, \quad \Gamma \equiv 1+\frac{(1-\theta) r k}{R V} .
$$

The IPO value will be negatively affected by increases in both the corporate income tax and the interest rate, while a rise in the expensing parameter stimulates firm value provided that the corporate tax is positive. 


\subsection{VC Financed Start-ups}

An entrepreneur's expected surplus is the utility difference between entrepreneurship and employment and reflects not only income differences but also various effort costs. First, seed investment is interpreted as a non-pecuniary private research effort which is required to prepare a business plan. Agents are taken to be distributed uniformly in the unit interval with respect to research ability and associated effort cost, $h^{i}=h \cdot i$. Once this effort is sunk, all start-up firms are assumed to be of uniform quality which cuts out any issues of adverse selection and helps to concentrate on the double moral hazard in VC backed firms. This is not to deny that selection effects are important, but only helps to focus on the value added role of $\mathrm{VCs} .{ }^{3}$

A start-up succeeds with probability $p$, leaving a value of $V$, and fails with $1-p$, leaving nothing. By the law of large numbers with independent risks, the number of mature firms becomes $N=p E$. The success probability $p=p(e, a)$ is concave in joint effort with decreasing returns to effort and is specified as

$$
p=p(e, a)=e^{\epsilon} a^{\alpha}, \quad \epsilon+\alpha<1 .
$$

VCs and entrepreneurs share expected firm value,

$$
\begin{aligned}
\pi^{E} & =(1-\tau)[s p V+B], \\
\pi^{F} & =(1-\tau)[(1-s) p V-B-(1-z) I], \\
\pi^{G} & =\tau[p V-(1-z) I]-z I, \\
\pi & =\pi^{E}+\pi^{F}+\pi^{G}=p V-I,
\end{aligned}
$$

where $\pi^{E}, \pi^{F}, \pi^{G}$ are expected incomes accruing to entrepreneurs, VCs and the government. Note that $\tau$ stands for a uniform capital gains tax on VCs and entrepreneurs. The government's surplus corresponds to the net tax revenue extracted from the project.

\footnotetext{
${ }^{3}$ Selection problems are discussed in the literature originating with DeMeza and Webb (1987) and Stiglitz and Weiss (1981), see De Meza (2002) for a recent summary. Ueda (2003) specifically investigates project selection of VCs. Fuest et al. (2003) study the relation between selection problems and corporate vs. personal taxes.
} 
Since VC funds are owned by households, the share of aggregate VC surplus per capita $\Pi$ fulfils $\Pi=\pi^{F} E$.

Let effort costs of the entrepreneur and the $\mathrm{VC}$ be given by $\beta e$ and $\gamma a$, respectively. In assuming competitive VCs, we allocate all bargaining power to the entrepreneur. Accordingly, the VC's surplus per venture, $\Omega^{F} \equiv \pi^{F}-\gamma a$, is squeezed to zero. Define the entrepreneur's profit net of effort cost as $\Omega^{E} \equiv \pi^{E}-\beta e$ which is uniform by our symmetry assumption. An entrepreneur's net surplus from incurring the seed investment and starting a business is then $\Omega^{E}-h^{i}-\left(1-t^{W}\right) W$, as she must also take account of foregone after-tax wage income and seed investment. When comparing expected welfare of the two career alternatives, all terms common to all occupations such as $\Pi+T$ and consumer surplus $C$ fall out. Therefore, $\Omega^{E}-h^{i}-\left(1-t^{W}\right) W$ gives the true utility differential between occupations. Having sunk $\left(1-t^{W}\right) W+h^{i}$, she is left to maximize her remaining surplus subject to the VC choosing to participate and subject to optimal effort choice of both parties after the contract is signed. The problem is

$$
\begin{aligned}
\Omega^{E}= & \max _{s, B}(1-\tau)[p(e, a) s V+B]-\beta e \quad \text { s.t. } \\
P C^{F}: & \Omega^{F}=(1-\tau)[p(e, a)(1-s) V-B-(1-z) I]-\gamma a \geq 0, \\
I C^{E}: & \Omega_{e}^{E}=p_{e}(e, a)(1-\tau) s V-\beta=0, \\
I C^{F}: & \Omega_{a}^{F}=p_{a}(e, a)(1-\tau)(1-s) V-\gamma=0 .
\end{aligned}
$$

At effort stage, where the agreed profit share $s$ is already fixed, optimal levels of efforts are determined by the two incentive compatibility constraints. Figure 2 illustrates the simultaneous choice of effort, using the functional form for $p(e, a)$ in (8). Both reaction curves $e(a)$ and $a(e)$ are positively sloped, implying that entrepreneurial effort and VC advice are strategic complements. According to Figure 2, and proved more precisely in the mathematical appendix, a larger expected IPO value boosts both the entrepreneur's effort and the VC's managerial support and thereby raises the firm's survival chances. An increase in the symmetric capital gains tax reduces the reward for effort and yields the 
opposite effects.

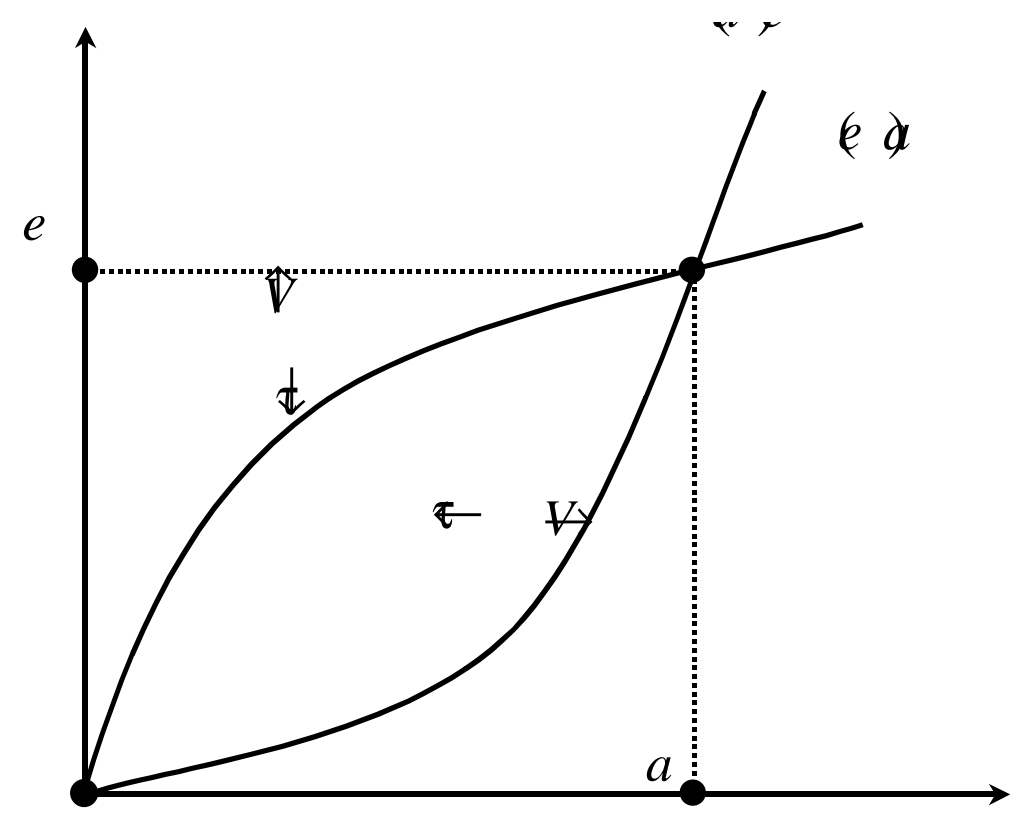

Figure 2: Effort and Advice

Anticipating effort choices, the entrepreneur proposes a deal such that the $\mathrm{VC}$ is willing to finance the investment expenditure and support the project with advice. The entrepreneur can raise her own expected profit by keeping either a larger share $s$ or demanding a higher upfront payment $B$ by asking for a price in excess of start-up cost $(1-z) I$. Note a fundamental difference between the two instruments $s$ and $B$. Claiming a higher $s$ reduces the VC's share and destroys her incentives to add value, while the upfront payment $B$ does not. The latter merely redistributes lump-sum across the two parties. The entrepreneur will therefore first choose $s$ to maximize joint surplus. Having found this Pareto optimal share $s$, she then requests a maximum upfront payment $B$ that allows the $\mathrm{VC}$ no more than to break even. In this way, the entrepreneur acquires the entire joint surplus $\Omega=\Omega^{E}+\Omega^{F}$. Substituting $B$ from (10.i) into (10) yields the entrepreneur's problem for choosing $s$, anticipating the incentive effects for later stage 
effort $e$ and $a$ as determined by (10.ii-iii):

$$
\Omega\left[\begin{array}{c}
V, \tau, z \\
+\underset{+}{-}+\underset{+}{+}
\end{array}\right]=\max _{s}(1-\tau)[p(e, a) V-(1-z) I]-\gamma a-\beta e \quad \text { s.t. (10.ii-iii). }
$$

With a symmetric capital gains tax on both entrepreneurs and VCs, the Pareto optimal profit share $s$ becomes independent of taxes and of venture returns $V$, as is shown in the mathematical appendix. We can thus take $s$ as a fixed constant, beyond the influence of policy. ${ }^{4}$

The joint surplus must be sufficiently large to compensate entrepreneurs for any foregone outside opportunity $\left(1-t^{W}\right) W$, and the initial effort cost $h^{i}=h \cdot i$ during the seed phase prior to VC finance. Entry of entrepreneurs occurs as long as $\Omega-\left(1-t^{W}\right) W-h \cdot i>$ 0 , until the marginal entrepreneur just breaks even. The free entry condition is, thus,

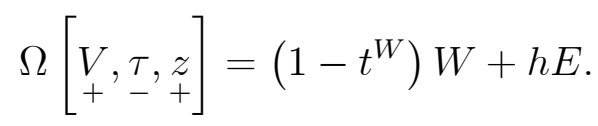

Figure 3 illustrates the relation between venture returns and the number of entrepreneurs. A higher venture return $V$, consisting of a higher IPO value of a maturing firm, raises the returns to start-up activity and leads more agents to choose an entrepreneurial career.

\footnotetext{
${ }^{4}$ In Keuschnigg and Nielsen (2004a) we show, though, that differential capital gains taxes on entrepreneurs and VCs, or a different tax treatment of the upfront payment $B$, can change the privately optimal equity share $s$, leading to more complicated comparative statics. For example, if VCs are taxed more heavily, it becomes more expensive for the team to rely on the VC's effort. It is then optimal to raise the share $s$ and rely more on the entrepreneur's effort.
} 
The other policy effects are directly inferred from the Figure.

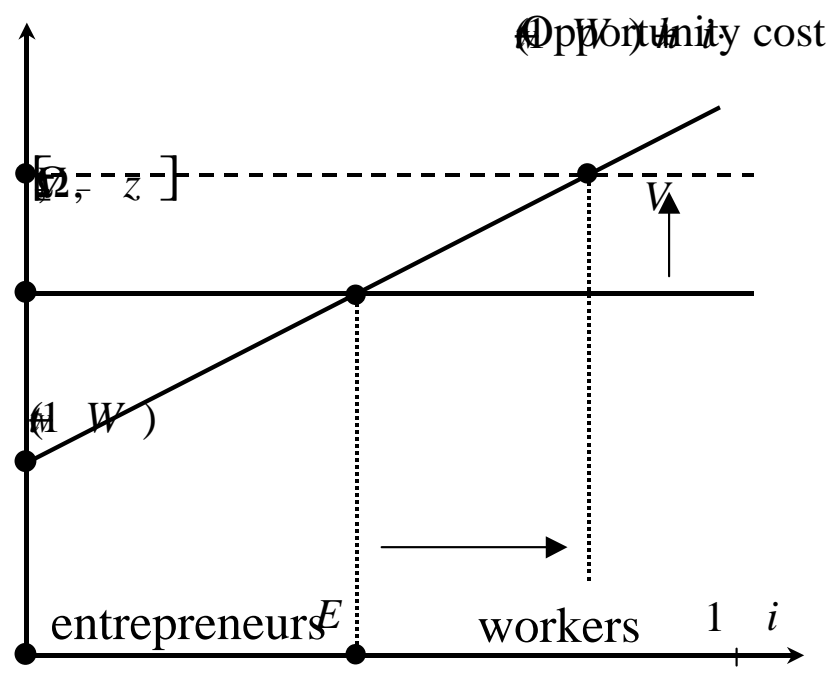

Figure 3: Start-up Entrepreneurship

\subsection{Equilibrium}

We now derive the equilibrium value $V$ of new firms. The demand for entrepreneurship reflects the demand $D$ for second period goods which requires a sufficiently large number $N=p E$ of mature firms,

$$
D=f(k) \cdot p E
$$

The success rate of start-ups is $p(V, \tau)$ since efforts $e, a$ are obviously functions of venture returns and the capital gains tax on new firms (viz. 10.ii-iii and Figure 2). In turn, the price of successful new firms is uniquely related to the interest rate and taxes as in (4). Total differentiation of (4) and using the derivatives given in (7) yields

$$
d V=-\frac{V_{1}+(1-\theta t) k}{R} d R-\frac{V}{1-t} \Gamma d t+\frac{t r k}{R} d \theta, \quad V\left[\begin{array}{c}
R ; \underset{+}{t}, \theta \\
-\underset{+}{+}
\end{array}\right] .
$$

An increase in the interest rate makes firm values fall while a rise in the corporate income tax or a reduction in tax depreciation likewise are associated with falling IPO prices. 
The supply per firm, $f(k)$, and total market demand $D$ both depend on the interest rate. Knowing $V$, one can thus derive the demand for entrepreneurs by inverting the equilibrium condition in (13),

$$
E^{D}\left[\begin{array}{c}
R ; t, \theta, \tau \\
++-++
\end{array}\right]=\frac{1}{p(V(R, t, \theta), \tau)} \cdot \frac{D(R)}{f(k(R, t, \theta))} .
$$

The demand for start-up entrepreneurship is upward sloping in $r$ (use $f^{\prime}(k)=u$ ),

$$
\frac{d E^{D}}{d R}=\frac{E}{D} D^{\prime}(R)-\frac{E}{f} u \frac{d k}{d R}-\frac{E}{p} \frac{d p}{d V} \frac{d V}{d R}>0 .
$$

Since $d p / d V$ and $D^{\prime}$ are both positive, and $d k / d R$ and $d V / d R$ both negative, all components contribute to a positive impact of the interest rate on the demand for start-up entrepreneurship. There are altogether three effects. First, a higher interest rate stimulates demand for second period goods and thus the demand for entrepreneurship. Second, a higher interest rate lowers investment in each mature firm, necessitating more firms to start up to meet second period goods demand. Third, a higher interest rate reduces the IPO price for successful new firms. Lower venture returns reduce the success rate of new firms, so that more of them must start up to secure a given level of goods demand in the second period. The upward sloping demand schedule in Figure 4 illustrates.

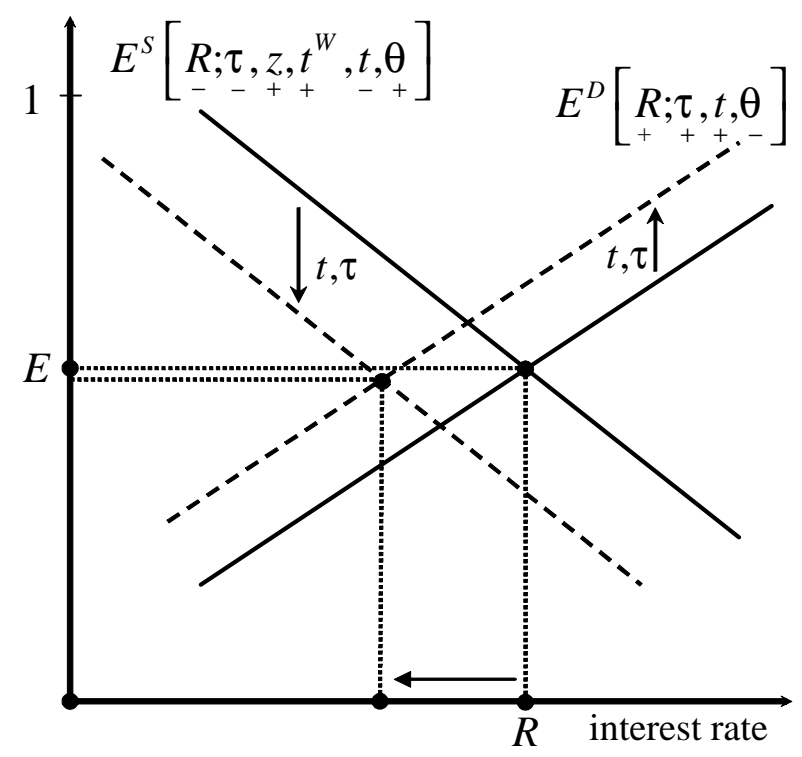

Figure 4: Equilibrium Venture Returns 
Taxes shift the demand schedule for entrepreneurs. An increase in the corporate income tax $t$ lowers investment in all firms, necessitating more firms to meet demand. Moreover, the higher tax lowers the price of successful new firms. This depresses efforts and the probability of success of new firms so that more of them have to start up to meet demand for second period goods. The opposite effects can be registered for an increase in the depreciation parameter $\theta$. Finally, a higher capital gains $\operatorname{tax} \tau$ raises the demand for entrepreneurship, since the tax reduces the returns to effort and thus cuts into the success rate, so that more firms must be created to satisfy any given demand for second period output.

The supply schedule in Figure 4 slopes down. Since an increase in the interest rate lowers venture returns, the entrepreneur's surplus $\Omega$ is reduced, so that fewer entrepreneurs find it worthwhile to incur the seed investment $h^{i}$ as illustrated in Figure 3. More formally, the free entry condition (12) yields

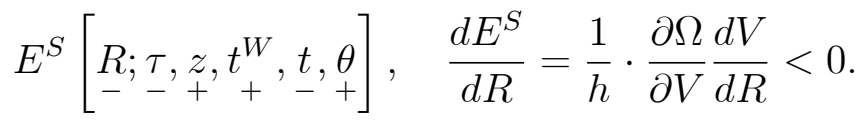

Apart from the negative interest rate effect on the supply of entrepreneurship, the capital gains tax likewise tends to reduce entrepreneurship on account of its negative effect on entrepreneurial surplus. In contrast, a higher start-up capital subsidy and a higher wage tax both stimulate entrepreneurship, since they boost the surplus created by entrepreneurial firms. Finally, the corporation tax subtracts from mature firm value $V$ and thereby the reward to entrepreneurship. Tax depreciation adds value and consequently encourages start-up activity which shifts up the entrepreneurial supply schedule. The free entry condition (12) and Figure 3 illustrate.

Equating demand and supply for entrepreneurship, $E^{D}=E^{S}$, yields the equilibrium number of start-up firms and the venture return $r$ which are uniquely tied to the IPO price $V$. Figure 4 illustrates. The comparative statics are simply derived by graphical arguments. 


\subsection{Welfare}

With risk neutrality and no distributional concerns, welfare is the sum of individual utilities and reflects efficiency. Utility in (2) includes monetary profits $\Pi=\pi^{F} E$ from ownership of VC firms. Since these profits are merely a compensation for intangible VC effort costs $\gamma a E$, we must subtract them. The welfare criterion is thus

$$
U^{*}=\int_{0}^{E} U^{* i} d i+U^{* L} L-\gamma a E
$$

Utility of a worker is $U^{* L}=\left(1-t^{W}\right) W+\Pi+T+C$. Referring to (12) and noting symmetry after the seed phase, utility of an entrepreneur is $U^{* i}=U^{* E}+h^{E}-h^{i}$. Utility of a low cost entrepreneur equals utility of the marginal one plus a rent reflecting her cost advantage in generating a business idea. Since the marginal entrepreneur is indifferent with respect to occupational choice, $U^{* E}=U^{* L}$. Noting $E+L=1$ as well as the participation constraint of VCs, $\pi^{F}=\gamma a$, we can compute a simple welfare formula,

$$
U^{*}=\left(1-t^{W}\right) W+T+C(R)+\int_{0}^{E}\left(h^{E}-h^{i}\right) d i, \quad C^{\prime}(R)=D / R^{2} .
$$

The last term reflects the rents of low cost entrepreneurs. Further, consumer rent from second period consumption increases with the interest rate.

Taking the differential of (19) and using the government budget constraint yields the welfare change relative to an untaxed initial equilibrium position. Detailed calculations are found in the mathematical appendix, section $\mathrm{C}$,

$$
d U^{*}=\left(p_{e} V-\beta\right) E d e+\left(p_{a} V-\gamma\right) E d a .
$$

The coefficients in (20) would be zero if effort and advice were chosen at their first best levels. First best efforts follow from maximizing the joint surplus in (11) without incentive constraints, and would satisfy the conditions $p_{e} V=\beta$ and $p_{a} V=\gamma$ in the absence of taxes. Since efforts are assumed not verifiable and contractible, neither the entrepreneur nor the $\mathrm{VC}$ is able to commit to first best effort, but will choose their inputs 
according to the incentive constraints (10.ii-iii). Since both agents must share the return on their effort within the team, but must fully bear their own cost, entrepreneurial effort and VC advice are too low in the private equilibrium. ${ }^{5}$ Even small taxes can thus give rise to first order welfare changes. Comparing with (10.ii-iii), the round brackets in (20) are both found to be positive. They reflect the excess of social over private returns to effort and advice. Since privately chosen effort tends to be underprovided in the presence of double moral hazard, any policy that boosts effort and advice must yield first order welfare gains.

\section{Policy and the Venture Capital Sector}

The European Venture Capital Association has recently benchmarked European countries with respect to their business climate for young VC financed firms, assessing among other things the levels of corporate taxes, especially for small and medium-sized companies, capital income taxes of personal investments in new firms, and fiscal subsidies to start-up investments (cfr. EVCA, 2004). Clearly, the VC industry regards taxes as an obstacle to VC financed start-up activity. It also seems to suggest that subsidies to loans or to physical investments in new firms would be desirable. However, our analysis casts doubt on this conclusion. Although successful in boosting the rate of business creation, startup subsidies may affect the quality of VC backed entrepreneurship quite unfavorably. Furthermore, a limited focus on the taxation of small firms cuts too short. The taxation of mature firms might be as important for start-ups as the direct taxation of infant companies. The corporate income tax may well reduce entrepreneurship even though the tax is only paid by mature companies rather than young ones. The basic insight is that by reducing the value of mature firms, the corporate tax diminishes the gains from setting up new companies as well. Finally, the taxation of wages is also relevant for start-up activity, since it direcly impacts on the entrepreneurs' alternative career opportunities.

\footnotetext{
${ }^{5}$ Such incentive problems in teams have been first analyzed by Holmstrom (1982).
} 
The model set up in the preceding section is well suited to study how fiscal policy might affect the joint efforts of entrepreneurs and VCs in new firms, the success probability of these, the level of entrepreneurship, venture returns, and welfare. Table 1 provides an overview of the main results. We emphasize intuitive explanations in the main text. For a more formal analysis of the proposed policy experiments, the reader is referred to the mathematical appendix.

\begin{tabular}{|c|c|c|c|c|c|c|}
\hline Type of tax & $R \quad E$ & $N$ & $V$ & $e$ & $a$ & $U^{*}$ \\
\hline \multicolumn{7}{|c|}{ mature firms } \\
\hline corporate $\operatorname{tax}^{\#)} t$ & $-\quad-$ & - & - & - & - & - \\
\hline $\operatorname{tax}_{\text {depreciation }}^{\#)} \theta$ & $+\quad+$ & + & + & + & + & + \\
\hline \multicolumn{7}{|c|}{ young firms } \\
\hline capital gains tax $\tau$ & $-\quad \pm$ & - & - & - & - & - \\
\hline start-up subsidy $z$ & $+\quad+$ & + & - & - & - & - \\
\hline \multicolumn{7}{|c|}{ occupational choice } \\
\hline wage tax $t^{W}$ & $+\quad+$ & + & - & - & - & - \\
\hline
\end{tabular}

Note: $R$ interest factor, $E$ young firms, $N$ mature firms, $V$ value of mature firm, $e$ entrepreneurial effort, $a$ venture capital advice, $U^{*}$ welfare.

\#) The change in the interest rate is unambiguous. A sufficient condition for the other comparative static results is $\sigma_{0} \geq \eta$.

\section{Table 1: Effects of Tax Policy}

\subsection{Corporate Taxation}

The effects of taxes are best understood in terms of demand and supply curves for entrepreneurial firms. The supply side reflects occupational choice of entrepreneurs. An increase in the corporate tax directly reduces the value of a mature firm which diminishes the entrepreneurs' surplus from creating a new one. Fewer entrepreneurs will want to incur the opportunity costs and give up alternative wages. Accordingly, the supply curve in Figure 4 shifts down. For any given interest rate, which determines the size of the output market, the demand for entrepreneurship follows from the number of firms $N$ 
needed to supply the market, $D=f(k) N$. A first policy effect derives from its impact on firm size which changes the number of mature firms needed to supply a given market. Since the corporate tax impairs expansion investment and thereby erodes output per mature firm, a larger number $N$ of firms is needed to serve the market which creates demand for entrepreneurship. Since only a fraction $p$ of new companies actually mature to production stage, $N=p E$, the number of young firms must necessarily be larger than the mass of established businesses which gives rise to a second supply effect. Since the corporate tax diminishes the IPO price equal to the value of a mature firm, it erodes the incentives for entrepreneurial effort and managerial advice and leads to an increased rate of business failure. Everything else equal, more new firms must be started for any given mass of mature firms serving the demand for second period output. Both effects shift up the demand schedule in Figure 4.

To eliminate the resulting excess demand for entrepreneurship, the interest rate must fall. Along the supply curve, entrepreneurship picks up, since a lower interest raises mature firm value which creates a larger surplus from business creation and thereby attracts more entrepreneurs to set up their own firm. Turning to the demand side, we find that a lower interest depresses savings and demand for second period output. Moreover, a lower interest boosts expansion investment, making mature firms bigger and thereby requiring fewer of them to serve the market. Further, the increased firm value boosts joint effort and thereby survival rates so that fewer start-ups are needed for any given number of mature firms. All three effects, i.e. smaller market, bigger mature firms, and a higher survival rate of young firms, add up to reduce demand for entrepreneurship along the demand curve. Apparently, the equilibrium effect on entrepreneurship seems to be ambiguous when both curves shift as illustrated in Figure 4. In the appendix (Keuschnigg and Nielsen, 2004c) we derive a sufficient condition for the net effect to be negative as stated in Table 1. The corporate tax reduces entrepreneurship if the tax is neutral with respect to expansion investment $(\theta=1)$, or if the interest elasticity of (second period) output demand $\sigma_{0}$ exceeds the elasticity $\eta$ of capital demand per firm with respect to the user cost, $\sigma_{0} \geq \eta$. In Figure 4 , a large $\sigma_{0}$ implies that any given interest increase triggers 
a large increase in market size, leading to a steep slope of the demand schedule. A small capital demand elasticity $\eta$ leads to a relatively smaller upwards shift of the demand curve. It can thus be illustrated graphically that this condition works to erode entrepreneurship following an increase in the corporate income tax.

A falling interest rate boosts firm value, while a higher tax reduces it. The direct tax effect dominates to reduce the value of a mature firm and thereby diminishes the returns to effort during the start-up phase. In consequence, entrepreneurial effort and VC support are discouraged which contributes to a higher rate of business failure. The corporate tax thereby leads to a first order welfare loss since efforts are already too low and the rate of business failure too high in the market equilibrium. This first order welfare loss is much more severe than the tax distortion of mature firm investment which results only in a second order welfare loss that would disappear for small taxes. We summarize:

Proposition 1 (Corporate Tax on Mature Firms) (a) The corporate income tax reduces market size and the equilibrium interest rate. The next results hold unambiguously if $\theta=1$, and hold under the sufficient condition $\sigma_{0} \geq \eta$ if $\theta<1$ : (b) The corporate tax decreases the number of start-up and mature firms and lowers firm value. (c) It impairs incentives for effort and advice and reduces the success probability. (d) A small tax increase entails a first order welfare loss.

The tax allowance $\theta$, i.e. the share of investment outlays immediately deductible from the current tax base, allows us to portray different systems of corporate income taxation. Note that we have assumed full depreciation of capital in each production period. Setting the tax allowance to zero corresponds to a Schanz-Haig-Simons corporate income tax with tax depreciation equal to economic depreciation in the second period, see section 2.3. In contrast, immediate expensing of investment outlays corresponding to $\theta=1$ represents a cash flow tax. Having undertaken an immediate write-off prevents, of course, further tax depreciation in the second period when capital actually depreciates economically. The cash flow tax is well known to be neutral with respect to investment, resulting in 
a marginal effective tax rate on expansion investment equal to zero. In this case, the user cost of capital in (4) exclusively depends on the rate of interest but is independent of the tax rate. However, the average effective tax rate of the cash flow tax (i.e. the share of corporate income paid in tax) is strictly greater than zero. Notwithstanding the neutrality of the cash flow tax with respect to marginal expansion investment, the tax burden is capitalized in a lower firm value. In reducing the IPO price, the cash flow tax does distort against discrete start-up investment. It also impairs the incentives of entrepreneurs and VCs to engage in their firms and thereby contributes to more frequent business failure. Given that joint efforts are already too low from a social perspective, the cash flow tax diminishes welfare and efficiency.

Of course, investment expensing is valuable only if the tax rate is positive already. Starting from this situation, we now consider an increase in the tax allowance $\theta$ which corresponds to a move towards a cash flow tax. A more generous allowance promotes expansion investment and, by reducing the average effective tax rate, boosts firm value. Given a larger value to be realized at IPO, entrepreneurs can expect a larger surplus from business creation and will accordingly start businesses more often. In consequence, the supply schedule in Figure 4 for young entrepreneurial firms shifts up. At the same time, the expectation of larger IPO values invigorates the joint effort in the start-up phase and contributes to improved survival rates. With higher survival chances, fewer firms need to be started for any given number of them to mature to production stage. The increased tax allowance further raises expansion investment and production in mature firms which likewise reduces the demand for entrepreneurship. The demand schedule in Figure 4 thus moves down for both reasons.

Obviously, to eliminate the resulting net supply of entrepreneurial firms, the interest rate must rise to force exit. Although a higher interest rates erodes firm values, it does not overturn the positive direct effect of the tax allowance. A higher IPO value boosts the return to effort and also encourages the VC to advise more intensively. Start-up firms accordingly benefit from this extra effort in terms of improved survival chances. Given 
that joint effort is too low initially, the tax allowance results in a first order welfare gain. Finally, the rate of business creation and the number of mature firms result from offsetting influences. First, the higher equilibrium interest rate reflects larger market size due to higher demand for second period output which expands the demand for both types of firms. Second, the tax allowance boosts marginal investments and makes mature firms bigger. The market supports a smaller number of them which negatively feeds back on the rate of business creation as well. The analysis in the appendix finds the net effect to be positive. Third, given that start-ups are more likely to mature to production stage, fewer of them are needed for any given number of firms on the product market. Again, the appendix reports a net positive effect.

Proposition 2 (Tax Allowance for Expansion Investment) (a) With a corporate tax in place, a more generous tax allowance for expansion investment raises equilibrium interest and boosts market size. The next results hold unter the sufficient condition $\sigma_{0} \geq \eta$ : (b) The tax allowance boosts firm values and raises the number of young and mature firms.

(c) In raising firm values, the allowance sharpens incentives for effort and advice and boosts the success probability. (d) By raising IPO values, the tax allowance stimulates effort and leads to first order welfare gains.

\subsection{Capital Gains Taxes and New Firms}

The immediate effect of a capital gains tax on young firms, given expected IPO values $V$, is to subtract from returns to effort and advice. The tax does not directly affect mature firm value which is exclusively determined by corporate taxes and the market interest rate. As illustrated in Figure 2, the tax discourages entrepreneurial effort and managerial advice and consequently results in a higher failure rate among start-up firms. The increased risk affects both the supply and demand schedules for entrepreneurship. In reducing the expected surplus from entrepreneurship, fewer agents find it worthwhile to start their own firm. The supply curve thus shifts down as indicated in Figure 4. On 
the demand side, the tax has no direct impact on market size and expansion investment of mature firms. However, on account of the reduced success probability of young firms, more entrepreneurs are required for any given number of firms to mature to production stage. The demand curve thus shifts up.

In face of the emerging excess demand for entrepreneurship, the interest rate must fall to reestablish equilibrium. The lower interest rate leads to lower savings and second period demand for goods, shrinks the market size. It also encourages mature firm investment and boosts firm values which, in turn, stimulate the returns to joint effort in the start-up phase. For all three reasons, smaller market size, larger mature firms, and a higher survival rate among start-ups, the demand for new firms falls along the demand curve and reduces entrepreneurship. The increase in firm values on the other hand boosts entrepreneurial surplus and stimulates the supply of new entrepreneurs along the supply curve. The net effect on the equilibrium number of start-up entrepreneurs remains ambiguous. The ambiguity arises despite the tax leading to a smaller number of mature firms. Mature firms also grow bigger since the falling interest rate spurs expansion investment. More entrepreneurs might nevertheless be needed since a lower success rate requires more startups for enough of them to mature to production stage.

While the tax discourages joint effort for any given IPO value $V$, the falling interest rate raises mature firm value and thereby sharpens incentives for effort. The appendix (see Keuschnigg and Nielsen, 2004c) shows that this price adjustment cannot dominate over the direct tax effect, implying lower effort and VC support and, hence, a lower success rate in equilibrium. By (20), the reduction in entrepreneurial effort and VC support leads to a welfare loss.

Proposition 3 (Capital Gains Tax on Start-up Firms) (a) A symmetric capital gains tax reduces the interest rate and market size. (b) On account of a lower rate of interest, the tax boosts mature firm value, raises expansion investment but reduces the number of mature firms. The change in the number of start-up firms is ambiguous. (c) 
The tax impairs incentives for effort and advice and reduces the survival probability. (d) Introducing a small capital gains tax on start-up firms entails a first order welfare loss.

A corollary of this proposition is that a small negative capital gains tax - or a revenue subsidy - for young firms will encourage effort and VC support and thereby contribute to higher welfare. However, a possible tax break in capital gains taxation must be limited to young VC backed firms only. We have also assumed full loss offset in capital gains taxation. The results on the capital gains tax are robust to restrictions on loss offset. Interestingly, the loss offset limitation can itself strengthen incentives for VC support in that the tax penalty arising from a limited loss offset makes business failure more costly (Keuschnigg and Nielsen, 2003b).

\subsection{A Subsidy to the Cost of Capital}

Most real world policies to encourage business creation allow for interest subsidies, loan guarantees to facilitate access to cheaper bank loans, or direct subsidies to investment spending. All these measures subsidize the cost of capital and are largely unrelated to firm performance. They can thus be understood as a subsidy to the cost of startup investment, captured by $z$ in our model. The only direct effect of an increase in the investment subsidy is to raise the entrepreneur's surplus from starting the firm and thereby to encourage entry, see (11) and (17). There are no other direct effects neither on effort and advice nor on the demand for start-up firms. In Figure 4, the subsidy thus shifts up the supply schedule, creating excess supply of entrepreneurs. The adjustment mechanism is well known by now. The interest rate must rise to stimulate savings and demand for second period output which leads to more demand for mature and young firms. At the same time, the increase in interest erodes firm value and entrepreneurial surplus which cuts back on entry and supply of new firms. The new equilibrium is characterized by a higher interest rate, larger market size and supports a larger number of entrepreneurs and mature firms. The higher interest retards mature firm investment and erodes firm values, see Table 1. 
The undesirable side effect of start-up subsidies is that they impair incentives for entrepreneurial effort and VC advice. The success probability correspondingly declines. The more successful these subsidies are in stimulating entry, the more likely should be the decline in venture returns and the stronger the negative welfare consequences. Note, however, that the welfare loss results from a general equilibrium effect rather than any direct impact. In a small open economy with a fixed interest rate, mature firm value should remain constant. In this case, the incentives for joint effort would remain untarnished and the subsidy would only produce increased entry. Since the entry margin is not distorted, the subsidy would entail a zero welfare effect in this case. ${ }^{6}$

Proposition 4 (Capital Subsidy to Start-ups) (a) A subsidy to start-up capital cost raises the interest rate and expands market size. (b) The subsidy expands the number of young and mature firms but erodes mature firm value. (c) It impairs incentives for effort and VC advice and reduces the survival rate. (d) Introducing a small subsidy entails a first order welfare loss.

The fact that a start-up subsidy and the capital gains tax both reduce welfare suggests the following strategy that would countribute to a more active VC industry but yet avoid any high cost to the general tax payer. Impose a tax $z<0$ on start-up investment cost and use the proceeds to finance a narrow tax break $\tau<0$ on capital gains to young $\mathrm{VC}$ backed firms. Since the entrepreneur is wealth-constrained, the start-up tax must be paid by the $\mathrm{VC}$ who should have no difficulty in raising capital and who will share the revenue subsidy with the entrepreneur when the venture succeeds. Being self-financed, the policy provides a net tax or subsidy equal to zero. A small start-up tax thus finances a cut in the capital gains tax rate by $(p V-I) d \tau=I d z$.

Consider first the direct impact for a given mature firm value $V .^{7}$ The direct effects

\footnotetext{
${ }^{6}$ Assuming a fixed interest as in a small open economy would not change the qualitative results of propositions 1 and 2 which do not hinge on the general equilibrium effects on the interest rate.

${ }^{7}$ For a more formal exposition of the effects of the self-financing policy we refer to Keuschnigg and Nielsen (2004a).
} 
on entrepreneurial surplus from the investment tax and from the revenue subsidy exactly cancel out because the policy is constructed to be self-financing. However, the tax break on $\tau$ strengthens incentives, thereby boosting joint effort as illustrated in Figure 2, and consequently increases the success rate as well. As a result, the project surplus increases and encourages entry of entrepreneurial firms. The supply schedule in Figure 4 shifts up. At the same time and for any given $V$, the tax cut $\tau$ reduces the demand for entrepreneurship because it makes start-ups more successful by inducing more effort, see (15). Fewer firms are needed to satisfy goods demand if more of them mature to the production stage. The demand schedule shifts down. The equilibrium effect on entrepreneurship remains ambiguous, but the interest rate goes up to close the gap between demand and supply. Furthermore, it is easily shown that net venture values $(1-\tau) V$ increase on account of the tax cut. Accordingly, the self-financing policy stimulates joint effort and raises the survival rate in equilibrium as well. Again from (20), this brings about an improvement in welfare. ${ }^{8}$

Our framework hence essentially implies that public policy should not aim at more, but at more successful VC backed firms. Policy should not aim at the volume but at the quality of $\mathrm{VC}$ investments. This conforms quite well with the conclusions of Bottazzi and Da Rin (2002) and Hege et al. (2003) about VC in Europe. They argue that in Europe $\mathrm{VC}$ has expanded quite impressively over the last decade, but the impact on firm performance seemingly remained rather limited. If anything, this calls for a policy that sharpens incentives for more entrepreneurial effort and more active VC involvement. In our framework, the entry margin is undistorted, but the double moral hazard between entrepreneurs and VCs works to erode incentives for value creating effort. While in many countries current policy vis-a-vis start-up firms essentially consists in a series of subsidies to investment in these firms, coupled with taxation of capital gains, our analysis suggest that a combination of scaling down these subsidies while alleviating taxation of capital gains on VC backed investments would be beneficial.

\footnotetext{
${ }^{8}$ Note that the policy would work even better in an open economy where any adjustment in the interest rate and mature firm value is limited.
} 


\subsection{Wage Taxation}

The rate of business creation depends not only on the surplus created by new entrepreneurial firms but also on the entrepreneurs' alternative career prospects. For this reason, wage taxation is quite relevant for start-up activity as the empirical literature mentioned in the introduction emphasizes. The implications of wage taxation in our model are easily inferred. The wage tax exclusively influences the occupational choice decision. In reducing the opportunity cost of entrepreneurship, it stimulates entry of new entrepreneurs and thereby shifts up the supply schedule in Figure 4. To equilibrate demand and supply of new entrepreneurial firms, the interest rate must rise. The higher interest rate presses down the value of new firms at IPO. Lower venture returns, in turn, hurt effort and advice in start-up firms, harm their survival prospects and ultimately reduce welfare. The effects are qualitatively identical to the capital cost subsidy.

Proposition 5 (Wage Tax) (a) An increasing wage tax raises the interest rate and expands market size. (b) The tax expands entrepreneurship and the number of mature firms but erodes firm value. (c) It impairs incentives for effort and advice and reduces the survival probability. (d) Introducing a small wage tax leads to a first order welfare loss.

As a corollary, a subsidy to wage income would restrict entry, leading to fewer firms with higher values. The subsidy could raise welfare since increased firm values sharpen incentives for joint effort. The start-up investment tax in the preceding subsection and the wage subsidy in this subsection can be compared to DeMeza and Webb (1987) who argue, for entirely different reasons, that entrepreneurial entry should be discouraged.

\section{Conclusions}

This chapter has proposed an equibrium model of the venture capital industry and has investigated the consequences and appropriateness of fiscal policy for the quality and 
quantity of venture capital financed entrepreneurship. Such an analysis is important for several reasons. First, the creation of young entrepreneurial firms is a significant factor in promoting employment and innovation in a growing economy. Second, venture capital has become an increasingly important source of finance for start-up firms over the last decades in virtually all industrial countries. In combining financing of new firms with active advice and networking support, venture capital can importantly help the professionalization of their portfolio companies and add value to the investments. For this reason, venture capital backed firms tend to outperform similar firms without access to venture capital, making them a particularly important source of job growth and innovation in the economy. Third, the business community at large as well as the venture capital industry itself have repeatedly questioned whether existing public policies are sufficiently conducive to the development of start-ups firms. For instance, the European Venture Capital and Private Equity Association has twice issued a benchmarking report on the conditions for entrepreneurship in its member countries, pointing to the importance of fiscal subsidies to research and development and other early stage investment cost as well as corporate income taxes and taxes on capital gains accruing to individuals from their stakes in entrepreneurial firms.

Rather than simply arguing for high subsidies and low taxes to stimulate entrepreneurship, as is often done, a stringent theoretical framework is called for in order to appropriately assess the role of relevant taxes and subsidies in determining the level and quality of venture capital backed entrepreneurship and economic efficiency. We have proposed a structural equilibrium model of the venture capital industry that emphasizes the need for outside risk capital and points to the importance of incentive problems that entrepreneurs and financiers may face in a typical, innovative start-up company. With this formal framework at hand, we have derived some important policy implications. Our results imply that the taxation of capital gains derived from young firms may be quite harmful to the quality of venture capital financed entrepreneurship and may diminish welfare. 
Perhaps surprisingly, corporate taxes are not only harmful to the expansion investment and value of mature firms but could be equally harmful to start-up firms which have not yet begun to actually pay the tax. In reducing mature firm value to be realized at the end of the start-up phase, the corporate tax impairs the incentives of entrepreneurs and venture capitalists for effort and active advice at the early stage of the firm's development. It may therefore contribute to an overly high failure rate and harm the quality of venture capital backed firms. Most of the real world programs to stimulate business creation involves a subsidy to the cost of capital in one or the other form. However, since these subsidies are given early on and are not success-related, they are not useful for sharpening incentives for effort and advice. Because they boost the rate of business creation, they may actually reduce equilibrium venture returns and thereby discourage effort and advice within VC backed start-ups. When reducing the quality of entrepreneurship this way, investment subsidies may turn out to be quite undesirable.

Our insights on the role of taxes and subsidies shows that they can be combined in a self-financing way to improve the quality of venture capital investments. Instead of a subsidy, a tax on start-up capital cost is proposed with the revenue used to finance a selective tax cut on the capital gains derived from venture capital backed investment. This package replaces a non-performance related subsidy with a success related tax cut, sharpens incentives within start-up firms and should thereby contribute to a more active style of venture capital financing.

\section{References}

[1] Aghion, P., Tirole, J., 1994. The Management of Innovation. Quarterly Journal of Economics 109, 1185-1209.

[2] Audretsch, D.B., Lehmann, E., 2002. Debt or Equity? The Role of Venture Capital in Financing the New Economy in Germany, CEPR DP 3656.

[3] Bottazzi, L., Da Rin, M., 2002. Venture Capital in Europe and the Financing of Innovative Companies, Economic Policy 34, 231-269. 
[4] Casamatta, C., 2003. Financing and Advising: Optimal Financial Contracts with Venture Capitalists, Journal of Finance 58, 2058-2085.

[5] Cressy, R., 2002. Introduction: Funding Gaps, Economic Journal 112, F1-F16.

[6] Cullen, J.B., Gordon, R.H., 2002. Taxes and Entrepreneurial Activity: Theory and Evidence for the U.S., NBER WP 9015.

[7] De Meza, D., Webb, D.C., 1987. Too Much Investment: A Problem of Asymmetric Information, Quarterly Journal of Economics 102, 281-292.

[8] De Meza, D., 2002. Overlending?, Economic Journal 112, F17-F31.

[9] EVCA (European Private Equity and Venture Capital Association), 2004. Benchmarking European Tax \& Legal Environments, May 2004.

[10] Fuest, C., Huber, B., and S.B. Nielsen, 2003. Why Is the Corporate Tax Rate Lower Than the Personal Tax Rate? The Role of New Firms, Journal of Public Economics 87, 157-174.

[11] Gentry, W.M., Hubbard, R.G., 2000. Tax Policy and Entry into Entrepreneurship, American Economic Review 90, 283-287.

[12] Gompers, P.A., Lerner, J.P., 1998. What Drives Venture Capital Fundraising?, Brookings Papers on Economic Activity - Microeconomics, 149-192.

[13] Gompers, P.A., Lerner, J., 1999. The Venture Capital Cycle, Cambridge: MIT Press.

[14] Gompers, P.A., Lerner, J., 2001. The Venture Capital Revolution, Journal of Economic Perspectives 15, 145-168.

[15] Hart, O., 2001. Financial Contracting, Journal of Economic Literature 39, 1079-1100.

[16] Hege, U., Palomino, F., Schwienbacher, A., 2003. Determinants of Venture Capital Performance: Europe and the United States, RICAFE Working Paper No. 001, Financial Markets Group, London School of Economics.

[17] Hellmann, T., Puri, M., 2000. The Interaction Between Product Market and Financing Strategy: The Role of Venture Capital, Review of Financial Studies 13, 995-984.

[18] Hellmann, T., Puri, M., 2002. Venture Capital and the Professionalization of StartUp Firms, Journal of Finance 57, 169-197.

[19] Holmstrom, B., 1982. Moral Hazard in Teams, Bell Journal of Economics 13, 324-340.

[20] Inderst, R., Mueller, H.M., 2004. The Effect of Capital Market Characteristics on the Value of Start-Up Firms, Journal of Financial Economics 72, 319-356.

[21] Kaplan, S.N., Stromberg, P., 2001. Venture Capitalists as Principals: Contracting, Screening, and Monitoring, American Economic Review 91, 426-430. 
[22] Keuschnigg, C., 2003. Optimal Public Policy for Venture Capital Backed Innovation, CEPR DP 3850.

[23] Keuschnigg, C., 2004a. Taxation of a Venture Capitalist With a Portfolio of Firms, Oxford Economic Papers 56, 1-22.

[24] Keuschnigg, C., 2004b. Venture Capital Backed Growth, Journal of Economic Growth 9, 239-261.

[25] Keuschnigg, C., Nielsen, S.B., 2003a. Tax Policy, Venture Capital, and Entrepreneurship, Journal of Public Economics 87, 175-203.

[26] Keuschnigg, C., Nielsen, S.B., 2003b. Taxes and Venture Capital Support, European Finance Review 7, 515-539.

[27] Keuschnigg, C., Nielsen, S.B., 2004a. Start-ups, Venture Capitalists, and the Capital Gains Tax, Journal of Public Economics 88, 1011-1042.

[28] Keuschnigg, C., Nielsen, S.B., 2004b. Taxation and Venture Capital Backed Entrepreneurship, International Tax and Public Finance 11, 369-390.

[29] Parker, S.C., 2003. Asymmetric Information, Occupational Choice and Government Policy, Economic Journal 113, 861-882.

[30] Poterba, J.M., 1989a. Capital Gains Tax Policy Toward Entrepreneurship, National Tax Journal 42, 375-389.

[31] Poterba, J.M., 1989b. Venture Capital and Capital Gains Taxation, in: Summers, L.H. (ed), Tax Policy and the Economy, Vol. 3, Cambridge: MIT Press, 47-67.

[32] Repullo, R., Suarez, J., 2004. Venture Capital Finance: A Security Design Approach, Review of Finance 8, 75-108.

[33] Rosen, H.S., 2004. Entrepreneurship and Taxation: Empirical Evidence, in: Kanniainen, V., Keuschnigg, C. (eds.), Venture Capital, Entrepreneurship and Public Policy, CESifo Seminar Series, Cambridge: MIT Press, forthcoming.

[34] Schmidt, K.M., 2003. Convertible Securities and Venture Capital Finance, Journal of Finance 43, 1139-1166.

[35] Stiglitz, J.E., Weiss, A., 1981. Credit Rationing in Markets with Imperfect Information, American Economic Review 71, 393-410.

[36] Ueda, M., 2004. Bank Versus Venture Capital. Project Evaluation, Screening, and Expropriation, Journal of Finance 59, 601-621. 


\section{Mathematical Appendix}

This mathematical appendix derives comparative static and other results.

\section{A Effort, Advice and Profit Sharing}

Effort and advice are simultaneously determined as illustrated in Figure 2. To obtain the comparative static effects, we log-linearize the incentive constraints at an initial equilibrium position. The hat notation indicates a percentage change $\hat{x}=d x / x$ relative to the initial value $x$. For tax rates which can be zero at the initial equilibrium, we use the relative change of the tax price, $\widehat{1-\tau}=-d \tau /(1-\tau) \equiv-\hat{\tau}$. The functional form for the likelihood of success in (8) thus implies $\hat{p}=\epsilon \hat{e}+\alpha \hat{a}, \hat{p}_{e}=-(1-\epsilon) \hat{e}+\alpha \hat{a}$, and $\hat{p}_{a}=\epsilon \hat{e}-(1-\alpha) \hat{a}$. The linearized incentive constraints (10.ii-iii) are

$$
\begin{aligned}
& I C^{E}:(1-\epsilon) \hat{e}=\alpha \hat{a}+\hat{s}+\hat{V}-\hat{\tau}, \\
& I C^{F}:(1-\alpha) \hat{a}=\epsilon \hat{e}-\frac{s}{1-s} \hat{s}+\hat{V}-\hat{\tau} .
\end{aligned}
$$

Solving the system (A.1) for effort response yields

$$
\begin{aligned}
& \hat{a}=\frac{1}{1-\epsilon-\alpha}\left[\hat{V}-\hat{\tau}-\frac{s-\epsilon}{1-s} \hat{s}\right], \\
& \hat{e}=\frac{1}{1-\epsilon-\alpha}\left[\hat{V}-\hat{\tau}+\frac{1-s-\alpha}{1-s} \hat{s}\right], \\
& \hat{p}=\alpha \hat{a}+\epsilon \hat{e}=\frac{\alpha+\epsilon}{1-\epsilon-\alpha}(\hat{V}-\hat{\tau})+\frac{(1-s) \epsilon-s \alpha}{(1-\epsilon-\alpha)(1-s)} \hat{s} .
\end{aligned}
$$

Next we show that the profit share which is optimally chosen as in (11), is independent of policy parameters. The first order condition is

$$
\frac{d \Omega}{d s}=0: \quad\left[(1-\tau) V \cdot e p_{e}-\beta e\right] \cdot \hat{e} / \hat{s}+\left[(1-\tau) V \cdot a p_{a}-\gamma a\right] \cdot \hat{a} / \hat{s}=0 .
$$

Exploiting $e p_{e}=\epsilon p$ and $a p_{a}=\alpha p$ by (8), we find (10.ii-iii) to be equivalent to $\beta e=$ $(1-\tau) \epsilon p V s$ and $\gamma a=(1-\tau) \alpha p V(1-s)$. Substituting these relations together with the results in (A.2) into (A.3) yields after cancelling some terms $(1-s)(1-s-\alpha) \epsilon=$ $(s-\epsilon) s \alpha$, or

$$
s=\frac{1}{2}+\frac{1}{2} \frac{\epsilon-\alpha}{(1-\alpha) \epsilon} s^{2} .
$$

The Pareto-optimal profit share is independent of any other variables except for the elasticities $\epsilon$ and $\alpha$ that determine the effect of the two inputs on the success rate, $\hat{p}=$ $\epsilon \hat{e}+\alpha \hat{a}$. If both types of effort are equally effective in raising the firm's success rate, then (A.4) shows that the optimal profit share is $s=.5$ for $\epsilon=\alpha$. A simple graphical solution of (A.4) shows that the entrepreneur's share is chosen larger than a half if the firm's success rate depends relatively more on the entrepreneur's effort, $s>.5$ for $\epsilon>\alpha$. If the VC's input is more important, the joint interest is to rely relatively more on the VC's input and therefore allocating a larger share to the $\mathrm{VC}$, leading to $s<.5$ for $\epsilon<\alpha$. 


\section{B Equilibrium}

\section{B.1 Supply of New Firms}

To obtain the linearized supply curve as implied by (12), take the differential of (11):

$$
\begin{aligned}
d \Omega= & (1-\tau) p V \hat{V}-(1-\tau)[p V-(1-z) I] \hat{\tau}+(1-\tau)(1-z) I \hat{z} \\
& +\left[(1-\tau) e p_{e} V-\beta e\right] \hat{e}+\left[(1-\tau) a p_{a} V-\gamma a\right] \hat{a} .
\end{aligned}
$$

By the same steps used in deriving (A.4), the last terms emerge as $(1-\tau) \epsilon p V(1-s) \hat{e}$ and $(1-\tau) \alpha p V s \hat{a}$. Substituting (A.2) with $\hat{s}=0$ on account of (A.4) gives

$$
\frac{d \Omega}{1-\tau}=p V \Psi \hat{V}-[p V \Psi-(1-z) I] \hat{\tau}+(1-z) I \hat{z}, \quad \Psi=\frac{1-s \epsilon-(1-s) \alpha}{1-\epsilon-\alpha}>1 .
$$

Equations (11-12) show that $p V-(1-z) I$ must necessarily be positive, as otherwise the joint surplus would not cover the opportunity costs of entrepreneurship in (12). Since $\Psi>1$, the coefficient of the capital gains tax rate $\hat{\tau}$ is positive a fortiori. Thus, (B.1) establishes the signs of the joint surplus as noted in (11).

By (12), the surplus drives entry according to $d \Omega=h E \hat{E}-\left(1-t^{W}\right) W \hat{t}^{W}$. Equating with (B.1), the linearized supply schedule for start-ups is

$$
\frac{h \hat{E}}{1-\tau} \hat{E}=p V \Psi \hat{V}-[p V \Psi-(1-z) I] \hat{\tau}+(1-z) I \hat{z}+\frac{1-t^{W}}{1-\tau} W \hat{t}^{W} .
$$

The IPO value of a newly established firm in (4) is stated in (14) in differential form. Define $\hat{R} \equiv d R / R, \hat{\theta} \equiv d \theta, \hat{t} \equiv d t /(1-t)$ and express it in relative changes,

$$
\hat{V}=-\frac{V_{1}+(1-\theta t) k}{V} \hat{R}-\Gamma \hat{t}+\frac{t r k}{R V} \hat{\theta} .
$$

Substituting (B.3) into (B.2) yields the supply schedule in terms of the rate of return on new ventures,

$$
\begin{aligned}
\frac{h E}{1-\tau} \hat{E}^{S}= & -\left[V_{1}+(1-\theta t) k\right] p \Psi \hat{R}-\Gamma p V \Psi \hat{t}+\frac{t r k}{R} p \Psi \hat{\theta} \\
& -[p V \Psi-(1-z) I] \hat{\tau}+(1-z) I \hat{z}+\frac{1-t^{W}}{1-\tau} W \hat{t}^{W} .
\end{aligned}
$$

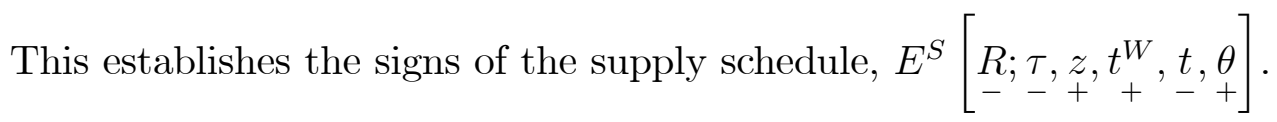




\section{B.2 Demand for New Firms}

Demand for capital in (6) depends on the cost of capital. Denoting the elasticity of capital demand by $\eta$ gives the second period output response of a mature firm,

$$
\hat{k}=-\frac{\eta}{(1-t) f^{\prime}}[(1-\theta t) R \hat{R}+(1-\theta) r \hat{t}-\operatorname{tr} \hat{\theta}], \quad \hat{f}=\frac{k f^{\prime}}{f} \cdot \hat{k}, \quad \eta \equiv-\frac{f^{\prime}}{k f^{\prime \prime}}>0 .
$$

Turning to the demand side as given by $u^{\prime}(D)=1 / R$, we denote the price elasticity of second period consumption by $\sigma_{0}$. Output demand thus depends on the interest rate as

$$
\hat{D}=\sigma_{0} \hat{R}, \quad \sigma_{0} \equiv-\frac{u^{\prime}(D)}{D u^{\prime \prime}(D)}>0
$$

The output market condition (13) is linearized as $\hat{D}=\hat{f}+\hat{p}+\hat{E}^{D}$. Using (A.2) for $\hat{p}$ and substituting the previous results leads to

$$
\hat{E}^{D}=\sigma \hat{R}+\frac{(1-\theta) \eta r k}{(1-t) f} \hat{t}-\frac{t \eta r k}{(1-t) f} \hat{\theta}-\frac{\alpha+\epsilon}{1-\epsilon-\alpha}(\hat{V}-\hat{\tau})
$$

where $\sigma$ is defined by

$$
\sigma \equiv \sigma_{0}+\frac{(1-\theta t) \eta R k}{(1-t) f}
$$

It is the demand elasticity for entrepreneurship with respect to the rate of interest $r$. Sub-

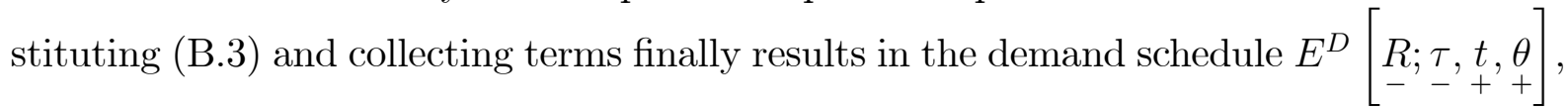
with elasticities according to

$$
\begin{aligned}
\hat{E}^{D}= & {\left[\sigma+\frac{\alpha+\epsilon}{1-\epsilon-\alpha} \frac{V_{1}+(1-\theta t) k}{V}\right] \hat{R}+\left[\frac{(1-\theta) \eta r k}{(1-t) f}+\frac{\alpha+\epsilon}{1-\epsilon-\alpha} \Gamma\right] \hat{t} } \\
& -\left[\frac{\eta}{(1-t) f}+\frac{\alpha+\epsilon}{1-\epsilon-\alpha} \frac{1}{R V}\right] \operatorname{trk} \hat{\theta}+\frac{\alpha+\epsilon}{1-\epsilon-\alpha} \hat{\tau} .
\end{aligned}
$$

\section{B.3 Equilibrium Venture Returns}

The equilibrium effects of policy interventions on venture returns follow upon equating demand and supply of start-up firms. Knowing how venture returns change in equilibrium, the effects on entrepreneurship can be read from either the demand or the supply schedule. Multiply (B.8) with $h E /(1-\tau)$ and equate with (B.4). After some tedious manipulations,

$$
\begin{aligned}
\Delta \hat{R}= & -\left[\left(\frac{(1-\theta) \eta r k}{(1-t) f}+\frac{\alpha+\epsilon}{1-\epsilon-\alpha} \Gamma\right) \frac{h E}{1-\tau}+\Psi p V \Gamma\right] \cdot \hat{t} \\
& +\operatorname{trk}\left[\left(\frac{\eta}{(1-t) f}+\frac{\alpha+\epsilon}{1-\epsilon-\alpha} \frac{1}{R V}\right) \frac{h E}{1-\tau}+\frac{\Psi p}{R}\right] \cdot \hat{\theta} \\
& -\left[\frac{\alpha+\epsilon}{1-\epsilon-\alpha} \frac{h E}{1-\tau}+\Psi p V-(1-z) I\right] \cdot \hat{\tau}+(1-z) I \cdot \hat{z}+\frac{1-t^{W}}{1-\tau} W \cdot \hat{t}^{W}, \\
\Delta \equiv & \left(\sigma+\frac{\alpha+\epsilon}{1-\epsilon-\alpha} \frac{V_{1}+(1-\theta t) k}{V}\right) \frac{h E}{1-\tau}+\left[V_{1}+(1-\theta t) k\right] p \Psi>0 .
\end{aligned}
$$


All coefficients are unambiguously signed by previous arguments. This equation proves the graphic illustration of the comparative static results.

A key variable to be known for the welfare results is firm value. Multiplying (B.3) by $\Delta$ and substituting (B.9) into (B.3) yields, after tedious arrangements using again $\Delta$

to simplify. To obtain the coefficient of $\hat{\theta}$, we have also replaced $\sigma=\sigma_{0}+\frac{(1-\theta t) \eta R k}{(1-t) f}$ and $V_{1}=\frac{(1-t)(f-u k)}{R}$ in $(4)$ to write $\sigma-\frac{\eta R V_{1}}{(1-t) f}=\sigma_{0}-\eta+\eta u k / f(k)$.

$$
\begin{aligned}
\Delta \hat{V} & =-\left[\sigma \Gamma-\frac{(1-\theta) \eta r k}{(1-t) f} \frac{V_{1}+(1-\theta t) k}{V}\right] \frac{h E}{1-\tau} \hat{t}+\left[\sigma_{0}-\eta+\frac{\eta u k}{f(k)}\right] \frac{h E}{1-\tau} \frac{t r k}{R V} \hat{\theta} \\
+ & \frac{V_{1}+(1-\theta t) k}{V}\left[\left(\frac{\alpha+\epsilon}{1-\epsilon-\alpha} \frac{h E}{1-\tau}+\Psi p V-(1-z) I\right) \hat{\tau}-(1-z) I \hat{z}-\frac{1-t^{W}}{1-\tau} W \hat{t}^{W}\right] .
\end{aligned}
$$

Hence, $\sigma_{0} \geq \eta$ is a sufficient condition for $\hat{\theta}$ to raise firm values. The same condition is sufficient to sign the effect on $\hat{t}$, see (D.3) below.

For the capital gains tax, we compute

$$
\Delta(\hat{V}-\hat{\tau})=-\left[\sigma \frac{h E}{1-\tau}+(1-z) I \frac{V_{1}+(1-\theta t) k}{V}\right] \hat{\tau}<0 .
$$

\section{Welfare}

To compute general equilibrium welfare results, we need to state the government budget constraint. To this end, it will be useful to relate the present value of the corporate tax base to private firm value $V$. Manipulating (4) eventually results in

$$
f_{1}-\theta k+\frac{f-(1-\theta) k}{R}=\frac{V}{1-t}+\frac{(1-\theta) r k}{(1-t) R}=\frac{V \Gamma}{1-t}
$$

where the last equality uses the definition of $\Gamma$ in (7). The present value $T=T_{1}+T_{2} / R$ of spending on transfers must be covered by the present value of tax revenue net of subsidies to businesses. Note that there are $E$ start-ups paying capital gains taxes but only $N=p E$ mature firms paying corporate taxes. The fiscal constraint is

$$
T=t^{W} W L+t \frac{\Gamma V}{1-t} p E+\tau[p V-(1-z) I] E-z I E .
$$

We consider small welfare effects relative to an untaxed equilibrium. The welfare effects follow from the differential of (19). Use the equilibrium condition $D=f \cdot p E$ as well as the specification of inventive ability $h^{i}=h \cdot i$,

$$
d U^{*}=d T-W d t^{W}+\frac{f p E}{R} \frac{d R}{R}+E h d E .
$$


Starting from an untaxed equilibrium, one must evaluate all derivatives at a position with zero taxes and subsidies. Occupational choice according to (12) implies $h d E=$ $d \Omega+W d t^{W}$. Taking the differential of (11) yields

$$
h d E=p d V-(p V-I) d \tau+I d z+W d t^{W}+\left(p_{e} V-\beta\right) d e+\left(p_{a} V-\gamma\right) d a .
$$

Replace $d V$ with the untaxed version of (14) which emerges, taking account of $V_{1}=$ $\frac{f}{R}-k$ in (4), as $d V=-\frac{f}{R} \frac{d R}{R}-\Gamma V d t$. Substitute this into (C.3) and the result into (C.2):

$$
\begin{aligned}
d U^{*}= & d T-W L d t^{W}-\Gamma p V E d t-(p V-I) E d \tau+I E d z \\
& +\left(p_{e} V-\beta\right) E d e+\left(p_{a} V-\gamma\right) E d a .
\end{aligned}
$$

For small deviations from an untaxed equilibrium, the first five terms will cancel. This is immediately seen by taking the differential of (C.2) at the zero tax position. Given the absence of tax base effects, first taxing the private sector and then rebating tax revenues as lump-sum transfers is merely a zero sum redistribution without any net loss. The first order efficiency gains or losses of such policy intervention is thus seen in the second line of (C.5).

\section{Output and Entrepreneurship}

We characterize the real effects of VC backed investment in several steps.

Industry Output: Demand for second period output defines the overall industry size $D=f(k) p E$ which is the output per firm $f(k)$ times the number $N=p E$ of successful start-ups that actually survived to production stage. Overall industry output changes in proportion to equilibrium venture returns and is given in (B.6), $\hat{D}=\sigma_{0} \hat{R}$.

Number of Mature Firms: The number of mature firms $N=p E$ is related to the interest rate by substituting (B.3) into (A.2) and combining the result with (B.8),

$$
\hat{N}=\sigma \cdot \hat{R}+\frac{(1-\theta) \eta r k}{(1-t) f} \cdot \hat{t}-\frac{\eta}{(1-t) f} t r k \cdot \hat{\theta}
$$

Policy affects firm size only with corporate taxation, depending on the tax rate $t$ and the investment allowance $\theta$. Other policy variables can affect mature firm size only via their impact on the (gross) rate of interest $R$. Comparing (D.1) and (B.9) reveals an ambiguity, since the direct effect of corporate taxes runs counter to the indirect effect via the interest rate. Substituting the relevant parts of (B.9) into (D.1) yields

$$
\begin{aligned}
\Delta \hat{N}= & -\left[\sigma \Gamma-\frac{(1-\theta) \eta r k}{(1-t) f} \frac{V_{1}+(1-\theta t) k}{V}\right]\left[\frac{\alpha+\epsilon}{1-\epsilon-\alpha} \frac{h E}{1-\tau}+\Psi p V\right] \cdot \hat{t} \\
+ & {\left[\sigma-\frac{\eta R\left[V_{1}+(1-\theta t) k\right]}{(1-t) f}\right]\left[\frac{\alpha+\epsilon}{1-\epsilon-\alpha} \frac{h E}{1-\tau}+\Psi p V\right] \frac{t r k}{R V} \cdot \hat{\theta} }
\end{aligned}
$$


The apparent ambiguity enters because of the effects on firm size. The tax allowance $\theta$ raises equilibrium returns in (B.9) and thereby expands market size. However, in spurring mature firm investment, it makes each firm larger, leaving fewer firms to serve the market. To resolve the ambiguity, substitute $\sigma \equiv \sigma_{0}+\frac{(1-\theta t) \eta k R}{(1-t) f}$ and use $V_{1}=\frac{(1-t)[f(k)-u k]}{R}$ from (4) into the coefficient of $\hat{\theta}$. The coefficient $\hat{t}$ is rewritten using $\Gamma=1+\frac{(1-\theta) r k}{R V}$ and $V_{1}+(1-\theta t) k=\frac{(1-t) f+(1-\theta) t k}{R}$ from $(4)$ :

$$
\begin{aligned}
\hat{\theta}: & \sigma-\frac{\eta R\left[V_{1}+(1-\theta t) k\right]}{(1-t) f} & =\sigma_{0}-\eta+\frac{\eta u k}{f} \\
\hat{t}: & \sigma \Gamma-\frac{(1-\theta) \eta r k}{(1-t) f} \frac{V_{1}+(1-\theta t) k}{V} & =\sigma+\frac{(1-\theta) r k}{R V}\left[\sigma_{0}-\eta+\eta k \frac{(1-\theta t) r+1-t}{(1-t) f}\right] .
\end{aligned}
$$

A sufficient condition for the tax allowance to boost the number of mature firms is $\sigma_{0}>\eta$. The corporate tax unambiguously reduces the number of mature firms in case of $\theta=1$ when it is neutral with respect to expansion investment. When $\theta$ falls, i.e. investment expensing becomes less generous, the tax retards expansion investment. The consequent reduction of output per firm demands a larger number of firms to serve the market. As for the sign of $\hat{\theta}$, a sufficient condition for the sign to remain robust is $\sigma_{0}>\eta$.

Start-up Entrepreneurship: The policy impact on entrepreneurship is necessarily more ambigous since there is an extra policy influence on the success probability via the impact on joint effort. In Figure $4, t, \theta, \tau$ shift both the demand and supply schedules. Since the wage tax and start-up subsidy have unambigous effects in Figure 4, we do not need to consider them here. The policy effects follow upon substituting (B.9) into the linearized demand curve. Some tedious steps result in

$$
\begin{aligned}
\Delta \hat{E} / \hat{\tau} & =-\sigma[\Psi p V-(1-z) I]+\frac{\alpha+\epsilon}{1-\epsilon-\alpha} \frac{V_{1}+(1-\theta t) k}{V}(1-z) I \gtrless 0, \\
\Delta \hat{E} / \hat{t} & =-\left[\sigma \Gamma-\frac{(1-\theta) \eta r k}{(1-t) f} \frac{V_{1}+(1-\theta t) k}{V}\right] \cdot p V \Psi, \\
\Delta \hat{E} / \hat{\theta} & =\left[\sigma-\eta \frac{R\left[V_{1}+(1-\theta t) k\right]}{(1-t) f}\right] \cdot \operatorname{trk} \frac{p \Psi}{R} .
\end{aligned}
$$

The coefficients for $t$ and $\theta$ involve the same proportional factors that were discussed in (D.2-3) to sign the comparative static effect. Obviously, the difference in the effects on the number of mature and start-up firms stems from the additional change in the success rate. Corporate taxation does not directly affect efforts except via its influence on firm value, thereby yielding the same qualitative effects as in (D.2).

The capital gains tax, however, has a direct negative impact on effort and survival probability which introduces an unresolved ambiguity in the number of start-ups. The tax reduces interest and, thus, contracts industry size and the number of mature firms which, for any given failure rate, also calls for fewer start-ups. With a higher failure rate, more firms need to be started for any given number of them to arrive on the product market. The net effect is ambiguous. 